\title{
The Diagnostic, Prognostic and Therapeutic Role of miRNAs in Adrenocortical Carcinoma: A Systematic Review
}

\author{
Chrysoula Mytareli ${ }^{1, *}$, Danae A. Delivanis ${ }^{2}$, Fani Athanassouli ${ }^{1}$, Vassiliki Kalotychou ${ }^{1}$, Marina Mantzourani ${ }^{1}{ }^{1}$, \\ Eva Kassi ${ }^{3,4}$ and Anna Angelousi ${ }^{1}$ (D) \\ 1 Department of Internal Medicine, Laikon General Hospital, Medical School, National and Kapodistrian \\ University of Athens, 11527 Athens, Greece; fani.athanasouli@yahoo.gr (F.A.); vkalotyc@med.uoa.gr (V.K.); \\ mantzourani@gmail.com (M.M.); a.angelousi@gmail.com (A.A.) \\ 2 Division of Endocrinology, Diabetes, Metabolism, and Nutrition, Mayo Clinic, Rochester, MN 55905, USA; \\ ddelivanis@gmail.com \\ 3 Department of Biological Chemistry, Medical School, National and Kapodistrian University of Athens, \\ 11527 Athens, Greece; evakassis@gmail.com \\ 4 Department of Propaedeutic and Internal Medicine, Laikon General Hospital, National and Kapodistrian \\ University of Athens, 11527 Athens, Greece \\ * Correspondence: Xrysam0804@gmail.com
}

check for

updates

Citation: Mytareli, C.; Delivanis, D.A.; Athanassouli, F.; Kalotychou, V.; Mantzourani, M.; Kassi, E.;

Angelousi, A. The Diagnostic,

Prognostic and Therapeutic Role of miRNAs in Adrenocortical Carcinoma: A Systematic Review. Biomedicines 2021, 9, 1501. https:// doi.org/10.3390/biomedicines9111501

Academic Editor: Ramón C. Hermida

Received: 2 September 2021

Accepted: 15 October 2021

Published: 20 October 2021

Publisher's Note: MDPI stays neutral with regard to jurisdictional claims in published maps and institutional affiliations.

Copyright: (c) 2021 by the authors. Licensee MDPI, Basel, Switzerland. This article is an open access article distributed under the terms and conditions of the Creative Commons Attribution (CC BY) license (https:// creativecommons.org/licenses/by/ $4.0 /)$

\begin{abstract}
Adrenocortical carcinoma (ACC) is a rare endocrine malignancy with a dismal prognosis and a high rate of recurrence and mortality. Therapeutic options are limited. In some cases, the distinction of ACCs from benign adrenal neoplasms with the existing widely available pathological and histopathological tools is difficult. Thus, new biomarkers have been tested. We conducted a review of the recent literature on the advances of the diagnostic, prognostic and therapeutic role of miRNAs on ACC patients. More than 10 miRNAs validated by multiple studies were found to present a diagnostic and prognostic role for ACC patients, from which miR-483-5p and miR-195 were the most frequently met biomarkers. In particular, upregulation of miR-483-5p and downregulation of miR-195 were the most commonly validated molecular alterations. Unfortunately, data on the therapeutic role of miRNA are still scarce and limited mainly at the experimental level. Thus, the role of miRNA regulation in ACC remains an area of active research.
\end{abstract}

Keywords: microRNAs; adrenocortical carcinoma; biomarkers; diagnosis; prognosis; therapy

\section{Introduction}

Adrenocortical tumors are common and are detected in 5-7\% of the general population [1] and up to $10 \%$ in the elderly [2]. Adrenocortical carcinoma (ACC) is an uncommon endocrine malignancy with an annual incidence of 1-2 cases per million [3] and with an extremely dismal prognosis with a 5-year survival rate of less than $35 \%$ [4]. Currently, the only curative therapy for localized ACC is surgery, although local recurrence is common, ranging from 19 to 34\% [5]. Adjuvant treatments, including chemotherapy and radiotherapy, have shown limited therapeutic effectiveness [6]. The most widely used classification system (tumor, lymph node and metastasis (TNM)) seems to be inadequate for predicting patient outcome and survival [7].

MicroRNAs (miRNAs) are small noncoding RNAs of 21-25 nucleotides that regulate genes expression in a sequence-specific manner, inhibiting their expression by targeting the $3^{\prime}$-untranslated region (3'-UTR) of target messenger RNA (mRNA) [8]. MiRNAs are considered epigenetic regulators, involved mainly in the post-transcriptional regulation of gene expression [8], and they are found not only in tissues but also in body fluids [9]. More than $50 \%$ of protein-coding human genes are predicted to be modulated by miRNAs. Deregulation of miRNAs has been implicated in the pathogenesis of many human diseases, particularly cancer. The link between miRNAs and cancer was brought about by the seminal observation of Croce's group, who reported that miR-15 and miR-16, two miRNAs 
located in chromosome 13 (13q14), are frequently deleted in chronic lymphocytic leukemia and function as tumor suppressors [10]. Since then, miRNAs have been studied more intensively in the field of cancer, and growing evidence suggests that altered miRNA expression is involved in the pathogenesis of various types of cancers.

Recent studies have identified miRNAs that have a functional role in adrenal tumorigenesis, including benign and malignant adrenocortical tumors and pheochromocytomas [11]. The role of miRNA deregulation in ACC was first suggested in 2007, when it was discovered that a long noncoding RNA H19 gene transcript [12] was detected in the 11p15 locus, where IGF2 is also located and associated with Beckwith-Wiedemann syndrome, which leads to the development of pediatric ACC [13]. Since then, a number of studies have been performed comparing miRNA expression in ACCs with normal adrenal cortex and adrenocortical adenomas (ACAs) [14]. Given the biological heterogeneity of ACCs and the limitations of the currently used treatments, a better understanding of miRNAs function may serve as a diagnostic, prognostic and potentially therapeutic tool in the management of these patients. In this systematic review, we present a critical summary of the recent observations describing miRNA dysfunction, focusing on their prognostic role in ACCs.

\section{Methods}

This systematic review was carried out according to the Preferred Reporting Items for Reviews and Meta-Analyses (PRISMA) statement.

\subsection{Data Sources and Search Strategy}

To identify studies and determine their eligibility, a systematic search was conducted in the PubMed and Cochrane Databases from 1 April to 15 April, 2021. The references of review articles and of included original publications were also screened for potentially relevant studies. Search terms included the following: "miRNAs", "adrenal tumours", "adrenal neoplasms", "adrenocortical carcinoma", "molecular biomarkers" and "epigenetics". The above keywords were also combined with the Boolean operators AND and OR.

\subsection{Eligibility Criteria for Articles of Inclusion}

A total of 1033 articles were retrieved from the search of the databases. After removing duplicates and non-English literature, 887 articles remained. Two of the authors (C.M and A.A) independently examined all potentially eligible titles and abstracts, from which 735 articles were excluded to identify 152 articles of interest. Studies on children (we included only 66 adults $>19$ years of age), as well as studies including other adrenal diseases or neoplasms (pheochromocytoma, benign adrenal neoplasms or hyperplasia $(n=60))$ than ACC and nonoriginal articles, were excluded. Articles assessing molecular biomarkers other than miRNAs were also removed. Full manuscripts were obtained as necessary to finalize eligibility (studies that were available only as abstracts were excluded). The articles were limited to those that presented information on the diagnostic, prognostic and therapeutic role of miRNAs in adrenocortical carcinoma. Twenty-nine studies qualified for inclusion in our study (Figure 1). 


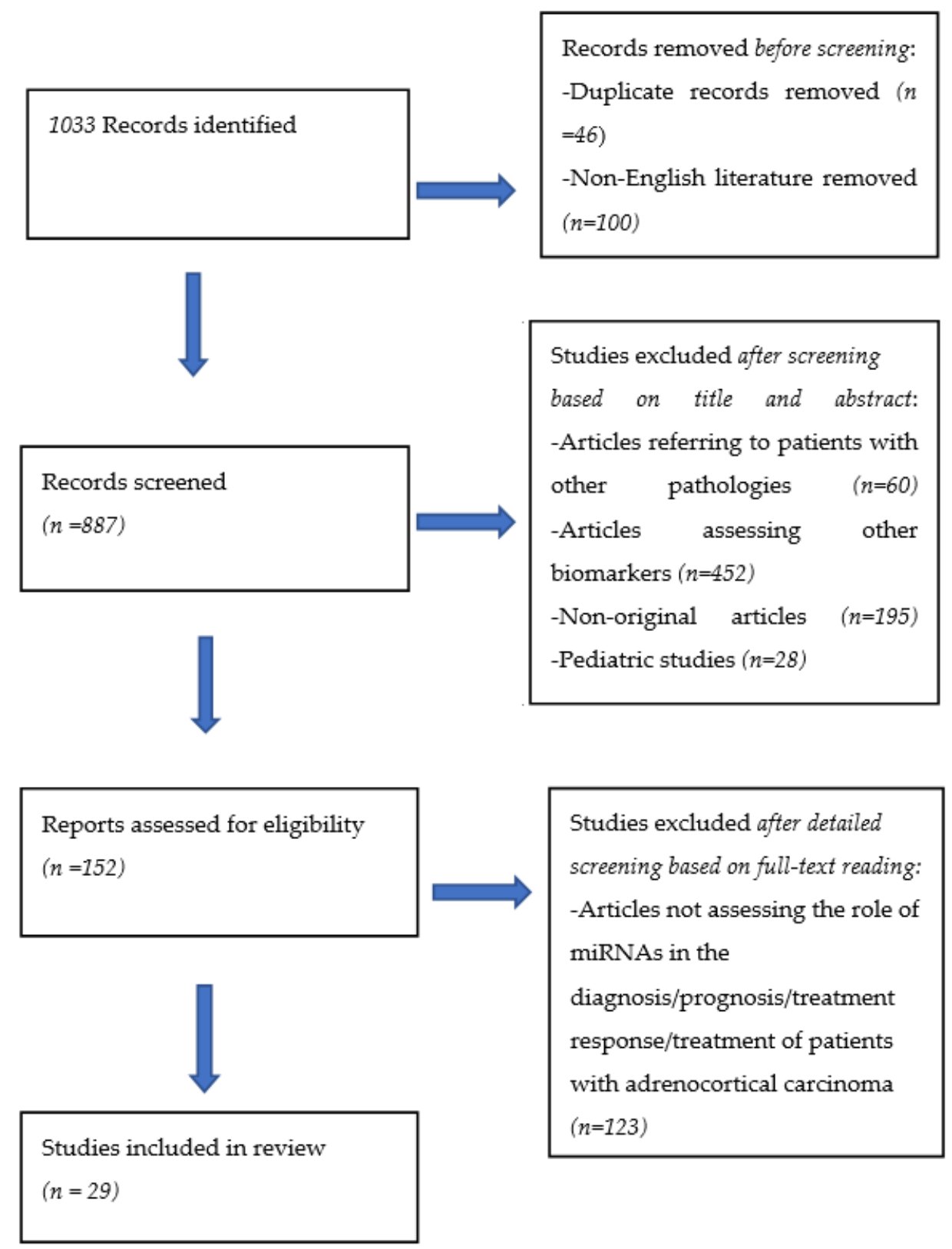

Figure 1. PRISMA flow diagram.

\subsection{Data Collection Process}

The full texts were carefully reviewed by the same reviewers who applied inclusion criteria. We collected the following data if available: the year of publication and name of the first author, the number of study participants, the pathologies, the study inclusion and exclusion criteria, the characteristics of the study participants, the type of samples that were used (tissue specimens or blood samples), the methods of miRNA isolation and the statistically significant test results.

\section{Results}

\subsection{The Diagnostic Role of miRNAs}

Twenty-two studies investigated the role of miRNAs in the diagnosis and prognosis of ACCs (Table 1). Fourteen studies [15-28] evaluated miRNAs' expression in adrenal tissues frozen or paraben embedded, six studies in blood samples [29-34] and two in both tissue and blood samples of patients diagnosed with adrenocortical tumors $[35,36]$. 
Table 1. Comparison of miRNAs' expression in adrenocortical carcinomas (ACCs), adrenocortical adenomas (ACAs) and/or normal adrenal cortices (NACs).

\begin{tabular}{|c|c|c|c|c|c|c|c|c|}
\hline \multirow{3}{*}{ Study } & \multirow{3}{*}{ Cohort (n) } & \multirow{3}{*}{$\begin{array}{c}\text { Method of } \\
\text { miRNA Isolation }\end{array}$} & \multirow{3}{*}{ Sample } & \multicolumn{4}{|c|}{ Dysregulated miRNAs } & \multirow{3}{*}{$\begin{array}{c}p \text {-Value } \\
\text { (for All } \\
\text { Comparisons) }\end{array}$} \\
\hline & & & & \multicolumn{2}{|c|}{ ACC vs. ACA } & \multicolumn{2}{|c|}{ ACC vs. NAC } & \\
\hline & & & & Upregulation & Downregulation & Upregulation & Downregulation & \\
\hline $\begin{array}{l}\text { Tombol et al., } \\
2009 \text { [16] }\end{array}$ & $\begin{array}{l}\mathrm{NAC}(10) \\
\mathrm{ACA}(19) \\
\mathrm{ACC}(7)\end{array}$ & TLDA & FFT & $\begin{array}{l}\text { miR-184, miR-210, } \\
\text { miR-503 }\end{array}$ & $\begin{array}{l}\text { miR-214, miR-511, } \\
\text { miR-375 }\end{array}$ & miR-184, miR-503 & $\begin{array}{l}\text { miR-214, } \\
\text { miR-511, } \\
\text { miR-375 }\end{array}$ & $<0.05$ \\
\hline $\begin{array}{l}\text { Patterson et al., } \\
2010 \text { [17] }\end{array}$ & $\begin{array}{l}\text { NAC(21), } \\
\mathrm{ACA}(26), \\
\mathrm{ACC}(10) / \\
\text { VC:ACA(35), NAC(21), } \\
\mathrm{ACC}(31)\end{array}$ & $\begin{array}{l}\text { Microarray } \\
\text { VC: RT-PCR }\end{array}$ & FFT & $\begin{array}{l}\text { Microarray: } \\
5 \text { miRNAs } \\
\text { upregulated } \\
\text {-VC: miR-483-5p } \\
\text {-Both: miR-483-5p }\end{array}$ & $\begin{array}{l}\text { Microarray: } \\
18 \text { miRNAs } \\
\text { downregulated } \\
\text {-VC: miR-100, } \\
\text { miR-125b, } \\
\text { miR-195 } \\
\text {-Both: miR-100, } \\
\text { miR-125b, } \\
\text { miR-195 }\end{array}$ & nd & nd & $\begin{array}{l}<0.01 \text { (for } \\
\text { comparisons via } \\
\text { microarray } \\
\text { analysis) } \\
<0.05 \text { (for } \\
\text { comparisons via } \\
\text { RT-PCR) }\end{array}$ \\
\hline
\end{tabular}


Table 1. Cont.

\begin{tabular}{|c|c|c|c|c|c|c|c|c|}
\hline \multirow{3}{*}{ Study } & \multirow{3}{*}{ Cohort (n) } & \multirow{3}{*}{$\begin{array}{c}\text { Method of } \\
\text { miRNA Isolation }\end{array}$} & \multirow{3}{*}{ Sample } & \multicolumn{4}{|c|}{ Dysregulated miRNAs } & \multirow{3}{*}{$\begin{array}{c}p \text {-Value } \\
\text { (for All } \\
\text { Comparisons) }\end{array}$} \\
\hline & & & & \multicolumn{2}{|c|}{ ACC vs. ACA } & \multicolumn{2}{|c|}{ ACC vs. NAC } & \\
\hline & & & & Upregulation & Downregulation & Upregulation & Downregulation & \\
\hline $\begin{array}{l}\text { Schmitz et al., } \\
2011 \text { [18] }\end{array}$ & $\begin{array}{l}\text { NAC(4), } \\
\operatorname{ACA}(9), \\
\operatorname{ACC}(7) / \\
\text { VC: ACT(15) }\end{array}$ & $\begin{array}{l}\text { Microarray } \\
\text { VC: RT-qPCR }\end{array}$ & FFPE & $\begin{array}{l}\text { Microarray: } 89 \\
\text { miRNAs } \\
\text { upregulated (vs. } \\
\text { Conn syndrome), } \\
35 \text { miRNAs } \\
\text { upregulated (vs. } \\
\text { Cushing } \\
\text { syndrome) }\end{array}$ & $\begin{array}{l}\text { Microarray: } \\
38 \text { miRNAs } \\
\text { downregulated } \\
\text { (vs. Conn } \\
\text { syndrome), } \\
159 \text { miRNAs } \\
\text { downregulated } \\
\text { (vs. Cushing } \\
\text { syndrome) } \\
\text {-VC: miR-335, } \\
\text { miR-675, } \\
\text { miR-139-3p } \\
\text {-Both: miR-335, } \\
\text { miR-675, } \\
\text { miR-139-3p }\end{array}$ & $\begin{array}{l}\text { Microarray: } \\
62 \text { miRNAs } \\
\text { upregulated }\end{array}$ & $\begin{array}{l}\text { Microarray:74 } \\
\text { miRNAs } \\
\text { downregulated } \\
\text {-VC: miR-139-3p, } \\
\text { miR-335, miR-675 } \\
\text {-Both: miR-335, } \\
\text { miR-675, } \\
\text { miR-139-3p }\end{array}$ & $\begin{array}{l}<0.05 \text { (for } \\
\text { comparisons via } \\
\text { microarray } \\
\text { analysis) } \\
<0.001 \text { (for } \\
\text { comparisons via } \\
\text { RT-PCR) }\end{array}$ \\
\hline
\end{tabular}


Table 1. Cont.

\begin{tabular}{|c|c|c|c|c|c|c|c|c|}
\hline \multirow{3}{*}{ Study } & \multirow{3}{*}{ Cohort (n) } & \multirow{3}{*}{$\begin{array}{c}\text { Method of } \\
\text { miRNA Isolation }\end{array}$} & \multirow{3}{*}{ Sample } & \multicolumn{4}{|c|}{ Dysregulated miRNAs } & \multirow{3}{*}{$\begin{array}{c}p \text {-Value } \\
\text { (for All } \\
\text { Comparisons) }\end{array}$} \\
\hline & & & & \multicolumn{2}{|c|}{ ACC vs. ACA } & \multicolumn{2}{|c|}{ ACC vs. NAC } & \\
\hline & & & & Upregulation & Downregulation & Upregulation & Downregulation & \\
\hline $\begin{array}{l}\text { Chabre et al., } \\
2013 \text { [35] }\end{array}$ & $\begin{array}{l}\text { NAC(19), } \\
\operatorname{ACA}(14), \\
\operatorname{ACC}(23)\end{array}$ & RT-qPCR & Serum & miR-139-5p & $\begin{array}{l}\text { miR-195, miR-335, } \\
\text { miR-376a }\end{array}$ & nd & $\begin{array}{l}\text { miR-195, miR-335, } \\
\text { miR-376a }\end{array}$ & $<0.05$ \\
\hline $\begin{array}{l}\text { Patel et al., } \\
2013 \text { [30] }\end{array}$ & $\begin{array}{l}\operatorname{ACA}(22) \\
\operatorname{ACC}(17)\end{array}$ & RT-qPCR & Serum & $\begin{array}{l}\text { miR-34a } \\
\text { miR-483-5p }\end{array}$ & - & nd & nd & $<0.011$ \\
\hline $\begin{array}{l}\text { Assie et al., } \\
2014 \text { [20] }\end{array}$ & NAC(3), ACC(45) & RNA sequencing & FFT & $\mathrm{Nd}$ & $\mathrm{Nd}$ & $\begin{array}{l}\text { miR-483-3, } \\
\text { miR-483-5p, miR-210, } \\
\text { miR-503, } \\
\text { miR-184, } \\
\text { miR-139-5P, } \\
\text { miR-376a }\end{array}$ & $\begin{array}{l}\text { miR-195, miR-335, } \\
\text { miR-214, miR-497 }\end{array}$ & $\mathrm{Nd}$ \\
\hline $\begin{array}{l}\text { Duregon et al., } \\
2014 \text { [21] }\end{array}$ & $\begin{array}{l}\mathrm{ACA}(47) \\
\mathrm{ACC}(51)\end{array}$ & RT-qPCR & FFT & $\begin{array}{l}\text { miR-483-3p, } \\
\text { miR-483-5p, } \\
\text { miR-210 }\end{array}$ & miR-195 & nd & nd & $<0.0001$ \\
\hline $\begin{array}{l}\text { Wang et al., } \\
2014 \text { [22] }\end{array}$ & $\begin{array}{l}\mathrm{ACA}(25) \\
\mathrm{ACC}(25)\end{array}$ & $\begin{array}{l}\text { In situ } \\
\text { hybridization }\end{array}$ & FFPE & $\operatorname{miR}-483-3 p$ & - & nd & nd & $<0.001$ \\
\hline
\end{tabular}


Table 1. Cont.

\begin{tabular}{|c|c|c|c|c|c|c|c|c|}
\hline \multirow{3}{*}{ Study } & \multirow{3}{*}{ Cohort (n) } & \multirow{3}{*}{$\begin{array}{c}\text { Method of } \\
\text { miRNA Isolation }\end{array}$} & \multirow{3}{*}{ Sample } & \multicolumn{4}{|c|}{ Dysregulated miRNAs } & \multirow{3}{*}{$\begin{array}{c}p \text {-Value } \\
\text { (for All } \\
\text { Comparisons) }\end{array}$} \\
\hline & & & & \multicolumn{2}{|c|}{ ACC vs. ACA } & \multicolumn{2}{|c|}{ ACC vs. NAC } & \\
\hline & & & & Upregulation & Downregulation & Upregulation & Downregulation & \\
\hline $\begin{array}{l}\text { Feinmesser et al., } \\
2015 \text { [23] }\end{array}$ & $\begin{array}{l}\mathrm{ACA}(25) \\
\mathrm{ACC}(8) / \\
\mathrm{VC}: \mathrm{ACA}(4), \mathrm{ACC}(11)\end{array}$ & $\begin{array}{l}\text { Microarray } \\
\text { VC: RT-qPCR }\end{array}$ & FFPE & $\begin{array}{l}\text { Microarray: Over } \\
\text { a dozen miRNAs } \\
\text { dysregulated } \\
\text {-VC: miR-503 } \\
\text {-Both: miR-503 }\end{array}$ & $\begin{array}{l}\text { Microarray: Over } \\
\text { a dozen miRNAs } \\
\text { dysregulated } \\
\text {-VC: miR-34a, and } \\
\text { miR-497 } \\
\text { (combination) } \\
\text { miR-335, } \\
\text { miR-195 } \\
\text {-Both: miR-34a } \\
\text { and miR-497 } \\
\text { (combination) } \\
\text { miR-335 } \\
\text { miR-195 }\end{array}$ & nd & nd & $<0.05$ \\
\hline $\begin{array}{l}\text { Gara et al., } \\
2015 \text { [24] }\end{array}$ & $\begin{array}{l}\mathrm{NAC}(21), \\
\mathrm{ACA}(26) \\
\mathrm{ACC}(10)\end{array}$ & Microarray & FFT & $\begin{array}{l}\text { miR-9, miR-25, } \\
\text { miR-124, miR-183, } \\
\text { miR-185, } \\
\text { miR-206 }\end{array}$ & - & $\begin{array}{l}\text { miR-9, miR-25, } \\
\text { miR-124, miR-183, } \\
\text { miR-185, miR-206 }\end{array}$ & - & $<0.05$ \\
\hline Wu et al., 2015 [25] & $\begin{array}{l}\operatorname{ACA}(21) \\
\operatorname{ACC}(11)\end{array}$ & RT-qPCR & Tissue & - & miR-205 & nd & nd & 0.008 \\
\hline $\begin{array}{l}\text { Zheng et al., } \\
2016 \text { [26] }\end{array}$ & $\begin{array}{l}\text { NAC(120) } \\
\operatorname{ACC}(79)\end{array}$ & RNA sequencing & FFT & $\mathrm{Nd}$ & $\mathrm{Nd}$ & $\begin{array}{l}\text { miR-10-5p, miR-48 } \\
\text { miR-22-3p, } \\
\text { miR-508-3p, } \\
\text { miR-509-5p, } \\
\text { miR-340, } \\
\text { miR-146a, } \\
\text { miR-21-3p, } \\
\text { miR-21-5p, } \\
\text { miR-509-3p, }\end{array}$ & - & $<0.05$ \\
\hline
\end{tabular}


Table 1. Cont.

\begin{tabular}{|c|c|c|c|c|c|c|c|c|}
\hline \multirow{3}{*}{ Study } & \multirow{3}{*}{ Cohort (n) } & \multirow{3}{*}{$\begin{array}{c}\text { Method of } \\
\text { miRNA Isolation }\end{array}$} & \multirow{3}{*}{ Sample } & \multicolumn{4}{|c|}{ Dysregulated miRNAs } & \multirow{3}{*}{$\begin{array}{c}p \text {-Value } \\
\text { (for All } \\
\text { Comparisons) }\end{array}$} \\
\hline & & & & \multicolumn{2}{|c|}{ ACC vs. ACA } & \multicolumn{2}{|c|}{ ACC vs. NAC } & \\
\hline & & & & Upregulation & Downregulation & Upregulation & Downregulation & \\
\hline $\begin{array}{l}\text { Koperski et al., } \\
2017 \text { [27] }\end{array}$ & $\begin{array}{l}\text { NAC( }(8) \\
\operatorname{ACA}(8) \\
\operatorname{ACC}(7) / \\
\operatorname{VC}: \operatorname{NAC}(10), \operatorname{ACA}(10), \\
\operatorname{ACC}(8)\end{array}$ & $\begin{array}{l}\text { RNA sequencing } \\
\text { VC: RT-PCR }\end{array}$ & FFPE & $\begin{array}{l}\text { RNA sequencing: } \\
\text { miR-503-5p, } \\
\text { miR-450a-5p, } \\
\text { miR-542-5p, } \\
\text { miR-483-3p, } \\
\text { miR-542-3p, } \\
\text { miR-450b-5p, } \\
\text { miR-210, } \\
\text { miR-483-5p, } \\
\text { miR-421, } \\
\text { miR-424-3p, } \\
\text { miR-424-5p, } \\
\text { miR-598, } \\
\text { miR-148b-3p, } \\
\text { miR-184 } \\
\text { miR-128 } \\
\text {-VC: miR-483-3p } \\
\text {-Both: miR-483-3p }\end{array}$ & nd- & $\begin{array}{l}\text { RNA sequencing: } \\
\text { miR-503-5p, } \\
\text { miR-450a-5p, } \\
\text { miR-542-5p, } \\
\text { miR-483-3p, } \\
\text { miR-542-3p, } \\
\text { miR-450b-5p, } \\
\text { miR-210, } \\
\text { miR-483-5p, } \\
\text { miR-421, } \\
\text { miR-424-3p, } \\
\text { miR-424-5p, } \\
\text { miR-598, } \\
\text { miR-148b-3p, } \\
\text { miR-184, } \\
\text { miR-128 }\end{array}$ & - & $<0.05$ \\
\hline $\begin{array}{l}\text { Koduru et al., } \\
2017 \text { [28] }\end{array}$ & $\begin{array}{l}\operatorname{ACA}(30) \\
\operatorname{ACC}(45)\end{array}$ & RNA sequencing & Tissue & $\begin{array}{l}\text { miR-483-3p, } \\
\text { miR-483-5p, } \\
\text { miR-153, } \\
\text { miR-135, } \\
\text { miR-514, } \\
\text { miR-210 }\end{array}$ & $\begin{array}{l}\text { miR-497, } \\
\text { miR-195, } \\
\text { miR-335, } \\
\text { miR-214, } \\
\text { miR-199 }\end{array}$ & nd & nd & $<9^{*} 10^{-6}$ \\
\hline $\begin{array}{l}\text { Perge et al., } \\
2017 \text { [32] }\end{array}$ & $\begin{array}{l}\mathrm{ACA}(6), \mathrm{ACC}(6) / \\
\mathrm{VC}: \mathrm{ACA}(18), \mathrm{ACC}(16)\end{array}$ & $\begin{array}{l}\text { Microarray } \\
\text { VC: RT-PCR }\end{array}$ & Plasma & $\begin{array}{l}\text { Microarray: } \\
\text { miR-101, } \\
\text { miR-483-5p } \\
\text {-VC: miR-101, } \\
\text { miR-483-5p } \\
\text {-Both: miR-101, } \\
\text { miR-483-5p }\end{array}$ & - & nd & nd & $\begin{array}{l}<0.05 \text { (for } \\
\text { comparisons via } \\
\text { microarray } \\
\text { analysis) } \\
<0.0052 \text { (for } \\
\text { comparisons via } \\
\text { RT-PCR) }\end{array}$ \\
\hline
\end{tabular}


Table 1. Cont

\begin{tabular}{|c|c|c|c|c|c|c|c|c|}
\hline \multirow{3}{*}{ Study } & \multirow{3}{*}{ Cohort (n) } & \multirow{3}{*}{$\begin{array}{c}\text { Method of } \\
\text { miRNA Isolation }\end{array}$} & \multirow{3}{*}{ Sample } & \multicolumn{4}{|c|}{ Dysregulated miRNAs } & \multirow{3}{*}{$\begin{array}{c}p \text {-Value } \\
\text { (for All } \\
\text { Comparisons) }\end{array}$} \\
\hline & & & & \multicolumn{2}{|c|}{ ACC vs. ACA } & \multicolumn{2}{|c|}{ ACC vs. NAC } & \\
\hline & & & & Upregulation & Downregulation & Upregulation & Downregulation & \\
\hline $\begin{array}{l}\text { Salvianti et al., } \\
2017 \text { [31] }\end{array}$ & $\begin{array}{l}\text { ACA(13), Stage } \frac{3}{4} \\
\operatorname{ACC}(27), \\
\text { NAC }(10)\end{array}$ & RT-PCR & Serum & miR-483 & - & $\operatorname{miR}-483$ & - & $<0.018$ \\
\hline $\begin{array}{l}\text { Decmann et al., } \\
2018 \text { [36] }\end{array}$ & $\begin{array}{l}\mathrm{ACA}(10), \\
\mathrm{ACC}(10) / \\
\mathrm{VC}: \mathrm{ACA}(14), \mathrm{ACC}(12)\end{array}$ & $\begin{array}{l}\text { Next-generation } \\
\text { sequencing } \\
\text { VC: RT-PCR }\end{array}$ & FFPE & $\begin{array}{l}\text { Microarray: } \\
\text { miR-184 } \\
\text { miR-483-5p } \\
\text { miR-483-3p } \\
\text { miR-183-5p } \\
\text {-VC: miR-184, } \\
\text { miR-483-5p, } \\
\text { miR-183-5p } \\
\text {-Both: miR-184, } \\
\text { miR-483-5p, } \\
\text { miR-183-5p }\end{array}$ & - & - & - & $\begin{array}{l}<0.001 \text { (for } \\
\text { comparisons via } \\
\text { microarray } \\
\text { analysis) } \\
<0.01 \text { (for } \\
\text { comparisons via } \\
\text { RT-PCR) }\end{array}$ \\
\hline $\begin{array}{l}\text { Perge et al., } \\
2018 \text { [33] }\end{array}$ & $\begin{array}{l}\operatorname{ACA}(26): \operatorname{NFA}(13), \\
\mathrm{CPA}(13) \\
\mathrm{ACC}(9)\end{array}$ & RT-PCR & Plasma & $\begin{array}{l}\text { miR-22-3p (related } \\
\text { to NFA,) } \\
\text { miR-27a-3p } \\
\text { (related to NFA), } \\
\text { miR-320b (related } \\
\text { to CPA and NFA) } \\
\text { miR-210-3p } \\
\text { (related to NFA) }\end{array}$ & - & nd & nd & $<0.05$ \\
\hline $\begin{array}{l}\text { Decmann et al., } \\
2019 \text { [34] }\end{array}$ & $\begin{array}{l}\mathrm{ACA}(23) \\
\mathrm{ACC}(23)\end{array}$ & RT-PCR & Serum & $\operatorname{miR}-483-5 p$ & - & $\mathrm{Nd}$ & nd & $<0.0001$ \\
\hline
\end{tabular}

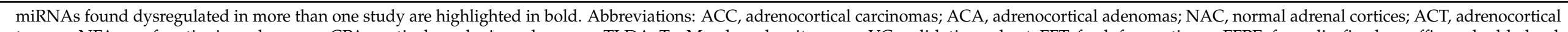

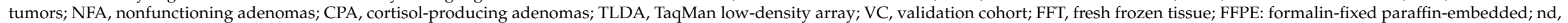
no data. 
MiR-483-5p is one of the most investigated miRNAs in ACCs, as it was found to be statistically significantly upregulated in ACCs compared with ACAs and/or healthy controls in 14 studies; 9 of them [15,17,19-21,26-28,35] included adrenal tissue samples, whereas the remaining 4 studies included blood samples [29,30,32,34] and the last both tissue and blood samples [36]. Furthermore, overexpression of miR-210 was also reported in ACCs compared with ACAs and/or healthy controls in seven studies; six in tissue [16,19-21,27,28] and one in blood samples [29]. MiR-483-3p and miR-503 were also overexpressed in ACC tissue samples in six $[19-22,27,28]$ and four $[15,16,20,23]$ studies accordingly. MiR483-3p was also found overexpressed in ACC plasma samples compared with ACAs in one study [36]. Furthermore, miR-184 was found upregulated in patients with ACC in five studies, four in tissue [16,20,27,36] and one in blood samples [29]. MiR-542-3p and miR-542-5p were also found upregulated in two studies in ACC tissues [15,27]. Finally, miR-139-5p and miR-181b were found upregulated in both ACC tissues and blood sample studies $[15,20,29,35]$.

The most common downregulated miRNAs in ACCs compared with ACAs and/or normal adrenal tissue samples included the following: the downregulation of miR-195 was validated in eight studies, all at the tissue level [15,17,19-21,23,28], except one study that included both tissue and blood samples [35]. The downregulation of miR-335 was validated in six studies; six in tissue samples [15,18,20,23,28,35], and the last also included blood samples [35]. Finally, miR-497 and miR-214 were also found downregulated in tissue samples in five $[19,20,23,28,35]$ and in three $[16,20,28]$ studies, respectively.

It is noteworthy that, in two studies, miRNA expression was studied through microarray analysis solely, in eight studies through RT-PCR, and in eight studies, results were validated by both microarray and RT-PCR analyses. However, in two studies, there were differences between the results of microarray analysis and qRT-PCR. In particular, in the study of Soon et al., the expression of miR-7 was found to be significantly lower in ACCs compared with ACAs on qRT-PCR, a result that had not been found in microarray analysis [15]. Additionally, in the study of Chabre et al., while microarray analysis indicated that miR-483-5p expression was not significantly different between ACCs and ACAs, RT-qPCR analyses revealed marked upregulation of miR-483-5p in ACCs compared with the ACAs of the validation cohort [35].

Tissue- and blood-circulating miRNAs levels were not always concordant. In the study of Patterson et al. [17], miR-100 was found downregulated in ACC tissue samples, while in the study of Szabó et al. [29], miR-100 was upregulated in the blood of ACC patients compared to patients with ACAs. A lower expression of miR-34a in ACC tumor samples compared to ACA was also observed [23], while Patel et al. found a higher expression of circulating miR-34a in the blood of ACC patients compared to patients with ACA [30]. Moreover, in the study of Chabre et al., an inverse correlation between miRNA expression in tumor samples and circulating blood levels was observed [35]. In particular, although miR-376a levels were found upregulated in ACC tissue samples and mainly in patients with aggressive ACC, its levels were significantly decreased in blood samples of the same patients compared with controls or ACA patients. In the study of Decmann et al., differences in the expression between tissue and blood miRNA levels were observed [36].

Finally, in another study, circulating miR-483-5p levels were found significantly overexpressed in the blood of ACC compared to ACA patients, whereas no significant difference was observed in their urinary samples [34].

\subsection{The Prognostic Role of miRNAs}

Data from 10 studies, 7 in tissues [15,19-21,23,37,38], 2 in blood samples [31,39] and the last in both tissue and blood samples [35], investigating the role of miRNAs as prognostic biomarkers in patients with ACC, were analyzed (Table 2). 
Table 2. miRNAs as prognostic biomarkers in ACCs.

\begin{tabular}{|c|c|c|c|c|c|c|}
\hline Study & Cohort (n) & Methodology & Sample & miRNAs & Outcome Studied & $p$-Value \\
\hline $\begin{array}{l}\text { Soon et al., } \\
2009 \text { [15] }\end{array}$ & 18 & Microarray & Tissue & $\uparrow \mathrm{miR}-483-5 \mathrm{p}, \downarrow$ miR-195 & $\begin{array}{l}\text { OS } \\
\text { (log-rank test) }\end{array}$ & $\begin{array}{l}0.036 \\
0.035\end{array}$ \\
\hline $\begin{array}{l}\text { Ozata et al., } \\
2011 \text { [19] }\end{array}$ & 22 & qRT-PCR & Tissue & $\uparrow \operatorname{miR}-503, \uparrow \operatorname{miR}-1202, \uparrow \operatorname{miR}-1275$ & $\begin{array}{l}\text { OS } \\
\text { (log-rank test) }\end{array}$ & $\begin{array}{l}0.006 \\
0.005 \\
0.042\end{array}$ \\
\hline $\begin{array}{l}\text { Chabre et al., } \\
2013 \text { [35] }\end{array}$ & 21 & qRT-PCR & Tissue & $\uparrow$ miR-139-5p, $\uparrow$ miR-376a, $\uparrow$ miR-376b, $\uparrow$ miR-376c & Local and distant recurrences & $\begin{array}{l}<0.0001 \\
<0.0001 \\
<0.05 \\
<0.05\end{array}$ \\
\hline $\begin{array}{l}\text { Chabre et al., } \\
2013 \text { [35] }\end{array}$ & 21 & qRT-PCR & Serum & $\uparrow \mathrm{miR}-483-5 \mathrm{p}, \downarrow$ miR-195 & $\begin{array}{l}\text { RFS and OS } \\
\text { (log-rank test) }\end{array}$ & $\begin{array}{l}0.0004 / 0.0005 \\
0.0014 / 0.0086\end{array}$ \\
\hline $\begin{array}{l}\text { Assie et al., } \\
2014[20]\end{array}$ & 45 & $\begin{array}{l}\text { RNA } \\
\text { sequencing }\end{array}$ & Tissue & $\begin{array}{l}\uparrow \text { Mi3 miRNA cluster } \downarrow \text { miR-508-3p, } \downarrow \text { miR-509-3p, } \downarrow \\
\text { miR-513-3p }, \downarrow \text { miR-514 }\end{array}$ & OS & nd \\
\hline $\begin{array}{l}\text { Duregon et al., } \\
2014 \text { [21] }\end{array}$ & 51 & qRT- PCR & Tissue & $\uparrow \operatorname{miR}-210$ & $\begin{array}{l}\text { OS } \\
\left(\log \text {-rank test/multivariate Cox model }{ }^{*}\right)\end{array}$ & $0.046 / 0.2195$ \\
\hline $\begin{array}{l}\text { Feinmessser } \\
\text { et al., } 2015 \text { [23] }\end{array}$ & 17 & qRT-PCR & Tissue & $\begin{array}{l}\uparrow \operatorname{miR}-483-3 p, \uparrow \text { miR-483-5p }, \uparrow \text { miR-10b }, \uparrow \operatorname{miR}-513-5 p, \uparrow \\
\text { miR-487a } \\
\uparrow \text { miR-503, } \uparrow \text { miR-210, } \downarrow \text { miR-497, } \downarrow \text { miR-34a, } \downarrow \text { miR-214, } \downarrow \\
\text { miR-99a }, \downarrow \text { miR-125b } \downarrow \text { miR-195, } \downarrow \text { miR-30c, } \downarrow \text { miR-15a, } \downarrow \\
\text { miR-335, } \downarrow \text { miR-345, } \downarrow \text { miR-708, } \downarrow \text { miR-29c }\end{array}$ & $\begin{array}{l}\text { Distant metastases and disease progression } \\
\text { (Spearman correlation) }\end{array}$ & $<0.05$ \\
\hline $\begin{array}{l}\text { Salvianti et al., } \\
2017 \text { [31] }\end{array}$ & 21 & qRT-PCR & Serum & $\uparrow \operatorname{miR}-483-5 p$ & $\begin{array}{l}\text { RFS and OS } \\
\left(\text { Log-rank test/multivariate Cox model }{ }^{* *}\right)\end{array}$ & $\begin{array}{l}\text { RFS: } 0.027 / 0.026 \\
\text { OS: } 0.001 / \mathrm{ns}\end{array}$ \\
\hline $\begin{array}{l}\text { Agosta et al., } \\
2018[38]\end{array}$ & 20 & qRT-PCR & Tissue & $\uparrow \operatorname{miR-139-5p}$ & $\begin{array}{l}\text { OS } \\
\text { (log-rank test) }\end{array}$ & $<0.0001$ \\
\hline $\begin{array}{l}\text { Oreglia et al., } \\
2020 \text { [39] }\end{array}$ & 26 & qRT-PCR & Serum & $\uparrow \mathrm{miR}-483-5 \mathrm{p}$ & $\begin{array}{l}\text { RFS and OS } \\
\left(\text { log-rank test } / \text { multivariate Cox model }{ }^{\neq} \text {) }\right.\end{array}$ & $\begin{array}{l}\text { RFS: } 0.0005 / 0.011 \\
\text { OS: } 0.007 / 0.150\end{array}$ \\
\hline
\end{tabular}


These miRNAs used as diagnostic markers to discriminate ACCs from ACAs seem to also differentiate aggressive from indolent ACCs. The upregulation of miR-483-5p in two studies in tissue $[15,23]$ and in three in blood samples $[31,35,39]$ has been associated with either short overall survival (OS), recurrence-free survival or disease progression. One study showed that high circulating levels of blood miR-483-5p postoperatively was associated with more than a four-fold increased risk of recurrence and was predictive of poor OS for ACC patients [39].

Moreover, overexpression of miR-503, miR-210 and miR-139-5p in the adrenal tissue of patients with ACC was associated with more aggressive behavior of the disease $[19,21,23,35,38]$. In particular, high miR-210 levels were associated with tissue necrosis and a high Ki-67 proliferation index [21]. The low expression of miR-195 was also observed in patients with aggressive ACCs in three studies (two in tissues, one in blood) $[15,23,35]$. MiR-139-5p and miR-376a levels were significantly upregulated in aggressive ACCs compared with non-aggressive ACC tumors samples, although no differences were observed in blood [35].

Eight out of ten studies [15,19,21,31,35,37-39] used Kaplan-Meier curves and the logrank test to associate the expression of miRNAs with prognosis, while three of them [21,31,39] performed univariate and multivariate Cox proportional hazard analysis. One study [23] performed only Spearman correlation to analyze the correlation of miRNAs with distant metastases and disease progression. Finally, Assie et al. [20] did not select single miRNAs to assess their prognostic role in ACCs but identified miRNA clusters correlated with groups of ACC patients with different prognoses.

\subsection{The Therapeutic Role of miRNAs}

The therapeutic potential of miRNAs was tested in two studies (Table 3). In the first study [40], it was shown that miR-7 replacement in vivo inhibits ACC xenograft growth in models derived from both the adrenocortical cell line (H295R) and primary ACC cells. The second and more recent study attempted to identify differentially expressed miRNAs between ACC patients responsive to adjuvant therapy (mitotane, chemotherapy and radiotherapy) and ACC patients resistant to adjuvant therapy with progressive disease on adjuvant treatment. MiR-431 was the most downregulated miRNA in the resistant group when compared with the sensitive group. In vitro restoration of $\mathrm{miR}-431$ enhanced the cytotoxic effects of doxorubicin and mitotane [41].

Table 3. MiRNA-based ACC treatments.

\begin{tabular}{cccccc}
\hline Study & Pathology & $\begin{array}{c}\text { miRNA-Based } \\
\text { Treatment }\end{array}$ & $\begin{array}{c}\text { Functional Role of } \\
\text { miRNAs in ACC }\end{array}$ & Type of Study & Outcome \\
\hline $\begin{array}{c}\text { Glover et al., } \\
2015 \text { [40] }\end{array}$ & $\begin{array}{c}\text { Metastatic } \\
\text { ACC }\end{array}$ & $\begin{array}{c}\text { Replacement } \\
\text { therapy: 10 doses } \\
\text { of miR-7 }\end{array}$ & $\begin{array}{c}\text { Cell proliferation } \\
\text { reduction by G1 cell } \\
\text { cycle arrest induction }\end{array}$ & $\begin{array}{c}\text { In vivo: } \\
\text { Patient-derived } \\
\text { xenograft in mice }\end{array}$ & Tumor reduction \\
\hline $\begin{array}{c}\text { Kwok et al., } \\
2019 \text { [41] }\end{array}$ & $\begin{array}{c}\text { Metastatic } \\
\text { ACC }\end{array}$ & $\begin{array}{c}\text { Replacement } \\
\text { therapy: miR-431 }\end{array}$ & $\begin{array}{c}\text { Cell death, EMT } \\
\text { reversal }\end{array}$ & $\begin{array}{c}\text { In vitro: ACC H295R } \\
\text { cells and primary- } \\
\text { derived ACC cells }\end{array}$ & $\begin{array}{c}\text { Increased ACC cell } \\
\text { response to doxorubicin } \\
\text { and mitotane }\end{array}$ \\
\hline
\end{tabular}

Abbreviations: EMT, epithelial-mesenchymal transition; ACC, adrenocortical carcinoma.

Several miRNAs were also validated as markers of treatment efficacy (Table 4). Circulating postoperative miR-105 blood levels were increased, whereas miR-483-5p decreased compared to preoperative levels in a small series of patients [35]. Postsurgical miR483 and miR-483-5p blood levels were also downregulated compared to presurgery levels in 27 ACC patients, although this decrease did not reach statistical significance [31]. Alteration in the expression of circulating miR-483-5p, miR-210, miR-181b and miR-184 levels was studied in four groups of patients with metastatic ACC: control, mitotane treated, 9-cis-retinoic acid treated and 9-cis-retinoic acid plus. It was found that only circulating blood miR-483-5p levels were significantly suppressed by the combined 9-cisRA + mitotane 
treatment in the ACC xenograft mouse model after treatment [42]. On the contrary, no significant changes were observed in the expression of tissue hsa-miR-483-5p between the four groups. In another preclinical study, levels of circulating blood miRNA-210 in the SW-13 tumor model were found to be elevated after combination therapy with etoposide, liposomal doxorubicin, liposomal cisplatin and mitotane, whereas no treatment-dependent changes were revealed for miR-483-5p [43].

Table 4. miRNAs as therapeutic biomarkers for ACC.

\begin{tabular}{|c|c|c|c|c|c|}
\hline Study & Type of Study & Treatment & $\begin{array}{l}\text { Post-Treatment } \\
\text { Marker's Level }\end{array}$ & Source & $p$-Value \\
\hline $\begin{array}{c}\text { Chabre et al., } \\
2013 \text { [35] }\end{array}$ & Clinical & Surgical removal & $\downarrow \mathrm{miR}-483-5 \mathrm{p}, \uparrow \mathrm{miR}-195$ & Serum & $<0.05$ \\
\hline $\begin{array}{l}\text { Nagy et al., } \\
2015 \text { [42] }\end{array}$ & $\begin{array}{l}\text { In vivo: Patient-derived } \\
\text { xenograft in mice }\end{array}$ & $\begin{array}{l}\text { Combined 9-cis retinoic acid + } \\
\text { mitotane treatment. }\end{array}$ & $\downarrow \mathrm{miR}-483-5 \mathrm{p}$ & Serum & 0.028 \\
\hline $\begin{array}{l}\text { Jung et al., } \\
2016 \text { [43] }\end{array}$ & In vivo: SW-13 xenograft & LEDP-M treatment & $\downarrow \mathrm{miR}-210$ & Serum & $<0.05$ \\
\hline
\end{tabular}

Upwards arrows $(\uparrow)$ indicate upregulation and downwards arrows $(\downarrow)$ indicate downregulation of miRNAs. Abbreviations: LEDP-M, etoposide, liposomal doxorubicin, liposomal cisplatin, mitotane.

\subsection{The Oncogenic Role of miRNAs}

The role of dysregulation of miRNAs in the oncogenic pathways of ACC has been studied in vivo and in vitro (Table 5, Figure 2). The miR-483 gene locus has been mapped to intron 2 of IGF2 [44], one of the most commonly overexpressed genes in ACC [45]. The high expression of miR-483-5p and miR-483-3p observed in ACC could be correlated with the high expression of IGF2. Moreover, the p53 upregulated modulator of apoptosis (PUMA) expression was found significantly downregulated in ACCs and inversely correlated with miR-483-3p expression [44]. Additionally, it was demonstrated that miR-483-5p and miR139-5p promoted ACC cell migration and invasion by suppressing the expression of two members of the N-myc downstream-regulated gene family NDRG2 and NDRG4 [38].

Table 5. miRNAs most frequently dysregulated in ACC compared to NAC or ACA.

\begin{tabular}{|c|c|c|}
\hline miRNA & Expression & Role of miRNAs in ACC Pathogenesis \\
\hline $\operatorname{miR}-483-5 p$ & Upregulated & $\begin{array}{l}\text { Promotes cell proliferation [19] } \\
\text { Promotes cell migration and invasion by suppressing expression of NDRG2 }{ }^{b} \text { [38] }\end{array}$ \\
\hline miR-195 & Downregulated & $\begin{array}{l}\text { Overexpression of miR-195 leads to decrease in cell growth and induction of cell } \\
\text { death [19] } \\
\text { Inhibits TARBP2 }{ }^{b} \text { and DICER gene expression [46] } \\
\text { Targets ZNF367 }{ }^{c} \text { and regulates cellular invasion [47] }\end{array}$ \\
\hline $\operatorname{miR}-210$ & Upregulated & Related to hypoxia parameters [21] \\
\hline $\operatorname{miR}-483-3 p$ & Upregulated & $\begin{array}{l}\text { Represses the proapoptotic gene BBC3/PUMA }{ }^{\mathrm{d}}[44] \\
\text { MiR-483-3p silencing suppresses cell proliferation and induces apoptosis [19] }\end{array}$ \\
\hline $\operatorname{miR}-335$ & Downregulated & 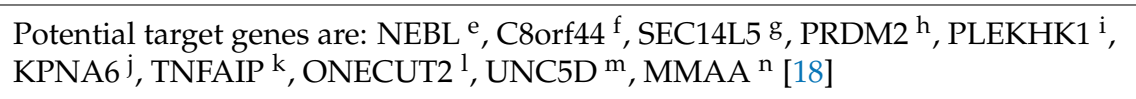 \\
\hline $\operatorname{miR}-497$ & Downregulated & $\begin{array}{l}\text { Overexpression of miR-497 reduces cell growth and induces apoptosis [19] } \\
\text { Inhibits DICER and TARBP2 }{ }^{\mathrm{b}} \text { gene expression [46] } \\
\text { Represses the lncRNA MALAT1 }{ }^{\circ} \text { and targets the EIF4E P. Its overexpression } \\
\text { suppresses cellular proliferation and induces cell cycle arrest [48] }\end{array}$ \\
\hline miR-184 & Upregulated & Unknown \\
\hline miR-503 & Upregulated & Unknown \\
\hline miR-214 & Downregulated & Unknown \\
\hline
\end{tabular}


Table 5. Cont.

\begin{tabular}{|c|c|c|}
\hline miRNA & Expression & Role of miRNAs in ACC Pathogenesis \\
\hline $\operatorname{miR-139-5p}$ & Upregulated & Promotes cell migration and invasion by suppressing expression of NDRG4 ${ }^{a}$ [38] \\
\hline miR-100 & Up- or downregulated & Regulates the IGF-mTOR q-raptor signaling pathway at multiple levels [49] \\
\hline $\mathrm{miR}-542-3 p$ & Upregulated & Unknown \\
\hline $\operatorname{miR}-542-5 p$ & Upregulated & Unknown \\
\hline $\operatorname{miR}-181 b$ & Upregulated & Unknown \\
\hline \multicolumn{3}{|c|}{ 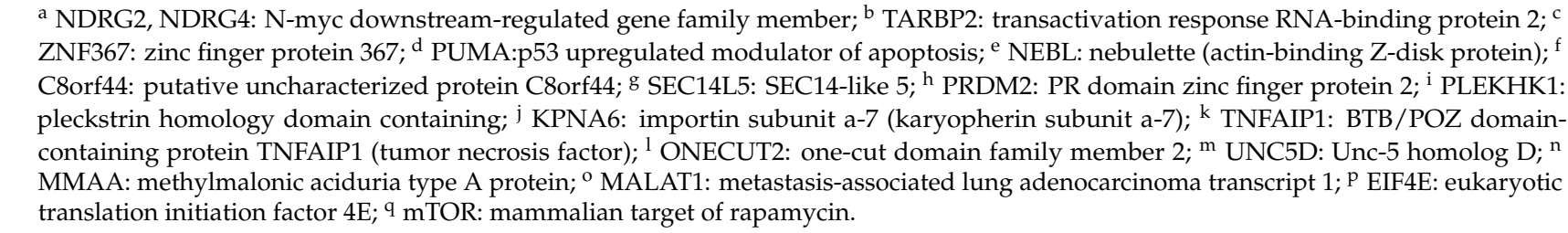 } \\
\hline
\end{tabular}

Dysregulation of four miRNAs was studied in vitro in human ACC cell lines [19]. Suppression of miR-483-5p and miR-483-3p expression led to a significant reduction in cell proliferation. Transfected cells with anti-miR-483-3p but not with anti-miR-483-5p resulted in a significant increase in apoptosis. Moreover, the overexpression of miR-195 or miR-497 resulted in a significant decrease in cell growth and induction of cell death through the suppression effect on both TARBP2 and DICER genes [46]. Inhibition of TARBP2 expression in human NCI-H295R ACC cells resulted in decreased cell proliferation and induction of cell apoptosis. Furthermore, the oncogenic mechanism of miR-497 could also be attributed to its ability to negatively regulate the expression of $M A L A T 1$, which, in turn, reversely competes for miR-497 binding to EIF4E [48]. It was observed that the overexpression of miR-497 and silencing of MALAT1 suppressed cellular proliferation and induced cell cycle arrest through downregulation of EIF4E expression. MiRNA-497 is a part of the miR-15 family cluster, located at the chromosomal region 17p13.1, in which there is a high frequency of loss of heterozygosity ( $\mathrm{LOH})$ in ACC compared to that of ACA neoplasms [50].

Additionally, miR-195 expression was inversely correlated with ZNF367 expression [47]. ZNF367 was overexpressed in ACCs compared to normal tissue and benign tumor and reduced cellular proliferation, invasion, migration and adhesion to extracellular proteins both in vitro and in vivo. Finally, molecular targets of miR-100 were also elucidated, such as IGF-1R and mammalian target of rapamycin (mTOR) signaling cascades [49].

Functional studies have demonstrated that miR-210 is a versatile molecule that regulates many aspects of hypoxia pathways, both in physiological and malignant conditions [51]. Although its role in ACC pathogenesis has not yet been elucidated, in the study of Duregon et al. [21], increased expression of miRNA-210 levels in tissue ACC samples was positively associated with necrosis and GLUT-1 expression. The inhibition of oxidative phosphorylation resulting from exposure to hypoxia leads to a stimulation of glucose transport, and this response is mediated by the enhanced function of glucose transporters, like GLUT-1 [52]. The relevance of miR-184, miR-503, miR-542-5p, miR-542-3p, miR-181b in the pathogenesis of ACC deserves further investigation.

However, these miRNAs are involved in the regulation of proliferation, invasion, apoptosis and other processes in various tumor cells. For example, research has suggested that the miRNA-184 can play a role as a tumor suppressor by inhibiting the proliferation and invasion of glioma [53], oral cancer [54] and lung cancer cells [55], and it can act as an oncogene by inhibiting apoptosis of renal cancer cells [56]. MiR-503 inhibits the G1/S transition by downregulating cyclin D3 and E2F3 in hepatocellular carcinoma [57], it inhibits cell proliferation and invasion in glioma by targeting L1CAM [58], it targets PI3K p85 and IKK- $\beta$ and suppresses the progression of non-small-cell lung cancer [58], and it inhibits cellular proliferation by targeting the AKT2 3'-UTR region in cervical cancer [59]. Moreover, there are many reports that demonstrate that miR-542-3p dysregulation is associ- 
ated with several malignancies. For example, Rang et al. [60] reported that miR-542-3p can directly target the protooncogene PIM1 in melanoma, and its downregulation can enhance melanoma cell migration, invasion, and epithelial-mesenchymal transition (EMT) in vitro and in vivo. Yang et al. [61] demonstrated that miR-542-3p regulates cortactin (CTTN) in a targeted manner to modulate the growth and invasion of colorectal cancer cells. Althoff et al. [62] reported that miR-542-3p exerts its tumor-suppressive function in neuroblastoma, at least in part, by targeting survivin. Zhang et al. [63] also found that miR-542-3p downregulation induces cancer metastasis and hyperactivity of the TGF- $\beta$ signaling pathway, thus promoting EMT and cancer progression in hepatocellular carcinoma. The role of the other mature sequence formed from pre-miR-542, miR-542-5p, has been described in tumors such as lung cancer [64], breast cancer [65], endometrial carcinosarcoma [66] and osteosarcoma [67]. Finally, the miR-181 family has been demonstrated to exert regulatory effects on tumorigenesis by modulating multiple signaling pathways, including PI3K/AKT, MAPK, TGF-b, Wnt, NF-kB and Notch pathways [68].

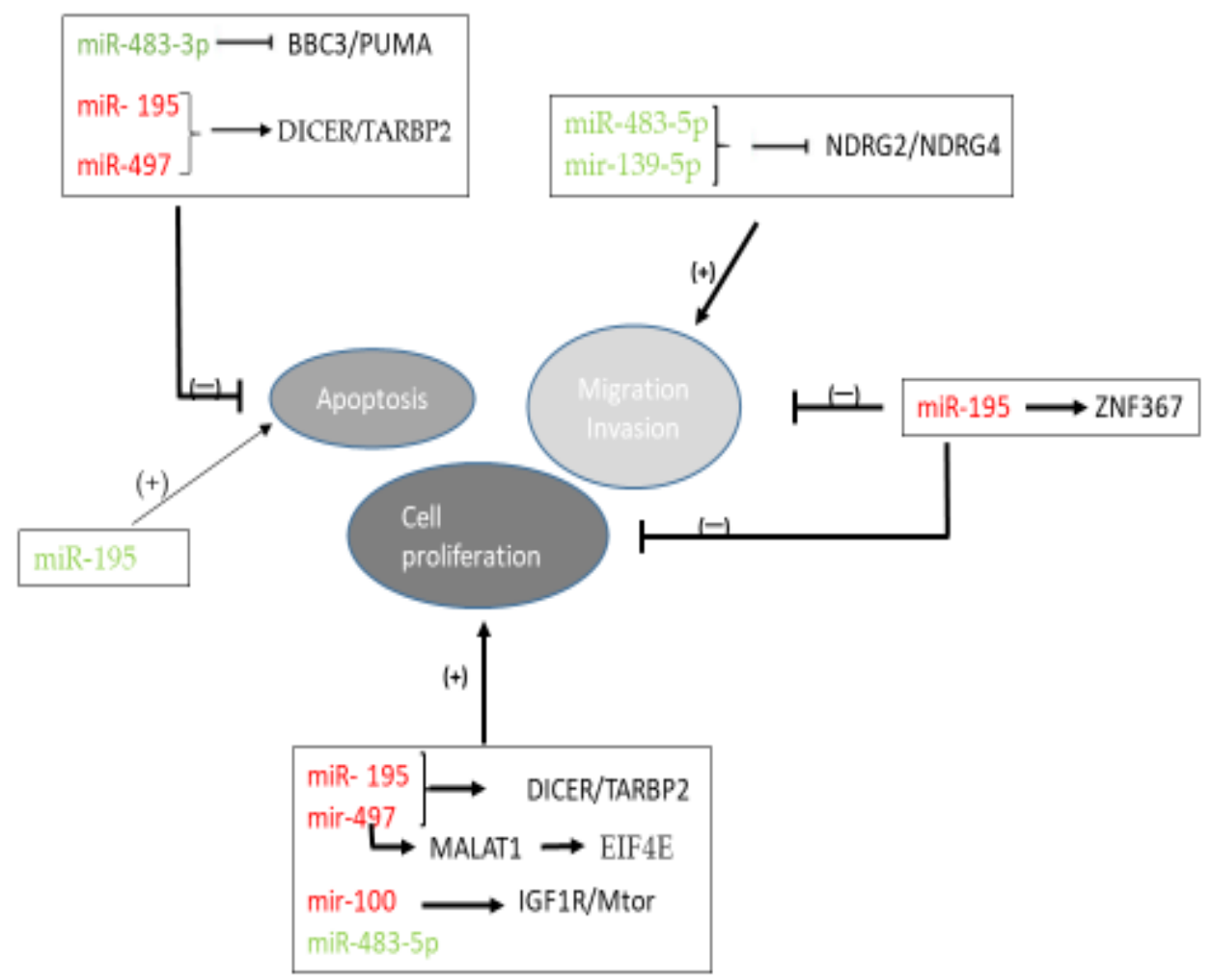

Figure 2. Schematic representation showing the miRNA- mediated mechanisms involved in ACC pathogenesis. Green fonts indicate upregulation and red fonts indicate downregulation of miRNAs. Arrows indicate stimulation, whereas T-arrows indicate inhibition. Abbreviations: BBC3; Bcl-2binding component 3, EIF4E; eukaryotic translation initiation factor 4E, IGF1R; insulin-like growth factor 1 receptor; MALAT1; metastasis-associated lung adenocarcinoma transcript 1, miR: microRNA; mTOR: mammalian target of rapamycin; NDRG; N-myc downstream-regulated gene family member, PUMA; p53 upregulated modulator of apoptosis, TARBP2; transactivation response RNA-binding protein 2, ZNF367; zinc finger protein 367.

\section{Discussion}

A number of studies have reported the expression of miRNAs in ACCs. Earlier studies using microarray and RT-q-PCR techniques could only investigate known miRNAs, whereas later studies utilizing RNA sequencing could identify differentially expressed miRNAs, which had not been previously characterized. In the present review, analyzing these data across the included studies, we identified that miR-483-5p, miR-210, miR-483-3p, miR-184, miR-503, miR-542-3p, miR-542-5p, miR-139-5p and miR-181b were upregulated 
in ACC patients compared with ACA and/or healthy controls in multiple datasets either in tissue or blood samples. On the contrary miR-195, miR-335, miR-497 the miR-214 were downregulated in ACC patients compared with ACA and/or healthy controls either in tissue or in blood samples.

More than $50 \%$ of miRNA genes are located in cancer-associated genomic regions or in fragile sites, suggesting that miRNAs play an important role in the pathogenesis of cancer [69]. MiR-483-5p is one of the most investigated miRNAs in ACCs, both as a diagnostic and prognostic biomarker, and has been proven as the best single-gene malignancy marker [27]. In the study of Chabre et al. [35], miR-483-5p levels were undetectable in the blood of healthy controls, ACA and nonaggressive ACC patients, whereas high levels were detected in the serum of patients with aggressive ACC. In addition to circulating blood $\mathrm{miR}-483-5 \mathrm{p}$, its urinary counterpart was evaluated in patients with adrenal tumors [34]. However, no significant difference was detected between ACC and ACA urinary samples. The lack of significance between ACC and adrenal myelolipoma in the expression of both tissue and plasma miR-483-5p and miR-483-3p might represent a limitation in the use of these markers, though [36].

The decrease in miR-483-5p blood levels after surgery in ACC patients suggests dynamic changes in serum miRNAs in response to surgical therapy [35]. This decrease was confirmed by another study [31] but did not reach statistical significance, probably due to the differences of sampling time in relation to the date of operation, as miRNAs deriving from the adrenal tumor before being removed may still be present in the bloodstream. Treatment-induced changes were also revealed for circulating miR-483-5p after systemic therapy in ACC patients [42].

Several miRNAs that seemed to be useful as differentiators between ACCs and ACAs are also promising prognostic indicators of ACCs. The statistically significant upregulation of miR-483-5p, miR-503, miR-210 and miR-139-5p and the downregulation of miR-19 were associated with poor clinical outcome in ACCs in most of the studies. Biomarkers that could predict the biological behavior of these tumors are essential in clinical practice, as they could identify high-recurrence-risk patients that need more intensive monitoring or adjuvant therapies and identify low-recurrence-risk patients that could avoid potential morbid therapies. Indeed, high miR-210 levels were found to be associated with ACC aggressiveness and poor prognosis, affecting the OS of these patients similarly with wellestablished prognostic factors such as mitotic count, Ki-67 proliferation index and increased expression of SF-1 [21]. Moreover, some miRNAs have been found differentially expressed in ACC histological variants. Prominent underexpression of miR-483-5p, miR-483-3p and miR-210 levels in adrenal tissues has been observed in oncocytic compared to the classical and myxoid histotype of ACC [21]. This interesting finding was interpreted through the prism of the positive correlation of the high levels of miRNA-210 expression with parameters of hypoxia, such as necrosis and GLUT-1, and aggressive biological behavior, such as mitotic rate and Ki-67 proliferation index, which are usually low in oncocytic tumors.

However, these results should be considered with great caution because the analysis of miRNAs expression, as well as its correlation with prognosis, differed among studies, either due to the different methodology used for molecular and/or statistical analysis. Several studies $[15,19,35,37,38]$ used Kaplan-Meier curves and the log-rank test to associate miRNA (low vs. high) levels with worse prognosis. Only three studies $[21,31,39]$ performed, in addition to the log-rank test, univariate and multivariate Cox proportional hazard regression analysis, including, however, different prognostic parameters in their multivariate model. In particular, Duregon et al. [21] included myxoid or classical ACC histotype (mitotic count $\geq 11, \mathrm{Ki}-67$ proliferation index $\geq 20$ ) SF-1 protein expression and $\mathrm{miR}-210$ and found that only mitotic count remains a significant prognostic factor. Salvianti et al. [31] included age, sex and miR483-5p and found that miR483-5p was associated with recurrence-free survival. Finally, Oreglia et al. [39] included tumor size, Ki67, ENSAT stage and miR-483-5p and found that miR483-5p was associated only with recurrence-free 
survival but not with OS. In addition, one study [31] performed only Spearman correlation to analyze the correlation of miRNAs with distant metastases and disease progression.

Another point of issue is the different cut-offs used for the expression of miRNA levels among the different studies. Receiver operating characteristic (ROC) analyses were performed to determine cut-off values in three studies [31,35,39], and only two studies $[15,37]$ used the dichotomized relative to the median value to determine cut-off values. Three studies [19,21,35] did not mention the cut-off value they used, whereas Agosta et al. [38] used the same cut-off values with Chabre et al. [35] study. Moreover, there was heterogeneity in the compared groups included in the ROC analyses. In particular, Chabre et al. [35] compared ACC patients with aggressive tumors defined as recurring tumors or tumors that were already metastatic at diagnosis with patients with nonaggressive ACC tumors. Oreglia et al. [39] divided patients with ACC into two groups: patients who showed a recurrence within 3 years (group $\mathrm{R}<3$ years) and patients who showed no recurrence during the first 3 years of follow-up. Salvianti et al. [31] divided ACC patients based on low (stage 1/2) versus high (stage 3/4) disease stages. Furthermore, the studied population concerning ACC patients was heterogenous among studies. For example, Duregon et al. [21] included also other than the classical histological types of ACC (oncocytic and myxoid), whereas Oreglia et al. [39] performed analyses only on postsurgical blood samples of patients with ACC.

Finally, all studies used data of miRNA expression deriving from RT-PCR but one [15], which used data from microarrays analysis. In the study of Ozata et al. [19], only three out of six miRNAs were found to present a statistically significant prognostic role, and the microarray-based results were also validated by RT-PCR.

Across several studies, differences in the expression between tissue and blood miRNA levels were observed, suggesting that the predictive role of blood miRNAs may be independent of tissue specimens. A potential explanation for this finding could be that released miRNAs do not reflect completely the cellular profile, as some miRNAs are retained or released selectively in the blood circulation [70].

Other components in the miRNA biogenesis pathway also seem to be useful as diagnostic and prognostic markers in adrenocortical tumors. Particularly, TARBP2, DICER and DROSHA miRNA-target genes are significantly overexpressed in ACCs when compared with adenomas and normal adrenal tissue samples [46]. A weak DICER1 protein expression is associated with reduced disease-free and OS serving as a predictor of recurrence in ACCs [71]. Furthermore, the top five upregulated target genes in ACCs, YWHAZ, GATA6, LDLR, BZW1 and IGFBP5, and five downregulated target genes, such as TXNIP, MAPKAPK5, PMAIP1, RAD51 and MICA, interact with several miRNAs [72].

Thus, identifying the relationships between miRNA signatures and ACCs could help better understand the underlying mechanisms and help develop new therapeutic strategies. Overexpression of miRNAs can be triggered by using synthetic miRNA mimics. Conversely, overexpressed miRNAs can be silenced by antagomiRs to restore miRNA balance in cancer networks [73]. For example, inhibition of miR-21 and miR-17-92 was associated with reduced tumor growth, invasion, angiogenesis and metastasis [74]. Indeed, the therapeutic potential of the miR-122 antagonist, miravirsen, in the treatment of hepatitis C was evident from a multicentric phase II trial [75]. Despite the great potential of miRNAs as novel therapeutic targets in the management of ACCs, there are a variety of technical challenges limiting the practical application of miRNA therapy in clinical practice, e.g., the availability of targeted delivery vesicles. Liposome delivery was the first delivery vehicle in clinical trials for miRNA [11]. Liposomal delivery of chemotherapeutics has already been studied in xenograft models of adrenocortical tumors. A significant reduction in tumor size was detected in an ACC xenograft model after a single treatment with anti-IGF1 receptor (IGF1-R) immunoliposomes (SSLD-1H7) [76]. Liposomally encapsulated miRNAs, in combination with cytostatic agents or alone, may represent a novel treatment option for ACC in the future. 


\section{Conclusions}

Despite significant advances in the understanding of the molecular landscape of ACC, major efforts are still needed to improve diagnosis, surveillance and treatment of patients with ACC. MiRNAs detected both in adrenal tissue and in human body fluids can be envisaged as potential noninvasive biomarkers of malignancy and/or disease recurrence. Altering the expression of the miRNAs might eventually expand the rather limited therapeutic repertoire in the management of adrenal tumors. The role of miRNA regulation in ACC remains an area of active research with the potential to further enhance our understanding of its tumor biology and the molecular pathways involved.

Author Contributions: Conceptualization, A.A.; methodology, A.A.; validation, A.A., V.K., D.A.D., E.K., F.A. and M.M.; investigation, A.A., C.M., D.A.D. and F.A.; writing-original draft preparation, A.A., C.M. and D.A.D.; writing-review and editing, A.A., C.M., D.A.D. and F.A.; supervision, A.A., V.K., D.A.D., E.K., M.M. All authors have read and agreed to the published version of the manuscript.

Funding: This research received no external funding.

Institutional Review Board Statement: Not applicable.

Informed Consent Statement: Not applicable.

Conflicts of Interest: The authors declare no conflict of interest.

\section{References}

1. Ebbehoj, A.; Li, D.; Kaur, R.J.; Zhang, C.; Singh, S.; Li, T.; Atkinson, E.; Achenbach, S.; Khosla, S.; Arlt, W.; et al. Epidemiology of adrenal tumours in Olmsted County, Minnesota, USA: A population-based cohort study. Lancet Diabetes Endocrinol. 2020, 8 , 894-902. [CrossRef]

2. Barzon, L.; Sonino, N.; Fallo, F.; Palu, G.; Boscaro, M. Prevalence and natural history of adrenal incidentalomas. Eur. J. Endocrinol. 2003, 149, 273-285. [CrossRef] [PubMed]

3. Else, T.; Kim, A.C.; Sabolch, A.; Raymond, V.M.; Kandathil, A.; Caoili, E.M.; Jolly, S.; Miller, B.S.; Giordano, T.J.; Hammer, G.D. Adrenocortical carcinoma. Endocr. Rev. 2014, 35, 282-326. [CrossRef]

4. Terzolo, M.; Bovio, S.; Pia, A.; Reimondo, G.; Angeli, A. Management of adrenal incidentaloma. Best Pract. Res. Clin. Endocrinol. Metab. 2009, 23, 233-243. [CrossRef] [PubMed]

5. Libé, R. Adrenocortical carcinoma [ACC]: Diagnosis, prognosis, and treatment. Front. Cell Dev. Biol. 2015, 3, 45. [CrossRef]

6. Libe, R.; Borget, I.; Ronchi, C.; Zaggia, B.; Kroiss, M.; Kerkhofs, T.; Bertherat, J.; Volante, M.; Quinkler, M.; Chabre, O.; et al. Prognostic factors in stage III-IV adrenocortical carcinomas [ACC]: An European Network for the Study of Adrenal Tumor [ENSAT] study. Ann. Oncol. 2015, 26, 2119-2125. [CrossRef]

7. Mizdrak, M.; Tičinović Kurir, T.; Božić, J. The role of biomarkers in adrenocortical carcinoma: A review of current evidence and future perspectives. Biomedicines 2021, 9, 174. [CrossRef]

8. Bartel, D.P. MicroRNAs: Target recognition and regulatory functions. Cell 2009, 136, 215-233. [CrossRef]

9. Cortez, M.A.; Bueso-Ramos, C.; Ferdin, J.; Lopez-Berestein, G.; Sood, A.K.; Calin, G.A. MicroRNAs in body fluids-The mix of hormones and biomarkers. Nat. Rev. Clin. Oncol. 2011, 8, 467-477. [CrossRef]

10. Calin, G.; Liu, C.-G.; Sevignani, C.; Ferracin, M.; Felli, N.; Dumitru, C.D.; Shimizu, M.; Cimmino, A.; Zupo, S.; Dono, M.; et al. MicroRNA profiling reveals distinct signatures in B cell chronic lymphocytic leukemias. Proc. Natl. Acad. Sci. USA 2004, 101, 11755-11760. [CrossRef]

11. Hassan, N.; Zhao, J.T.; Sidhu, S.B. The role of microRNAs in the pathophysiology of adrenal tumors. Mol. Cell. Endocrinol. 2017, 456, 36-43. [CrossRef]

12. Cai, X.; Cullen, B.R. The imprinted H19 noncoding RNA is a primary microRNA precursor. RNA 2007, 13, 313-316. [CrossRef]

13. Poole, R.L.; Leith, D.J.; Docherty, L.E.; Shmela, M.E.; Gicquel, C.; Splitt, M.; Temple, I.K.; Mackay, D.J. Beckwith-Wiedemann syndrome caused by maternally inherited mutation of an OCT-binding motif in the IGF2/H19-imprinting control region, ICR1. Eur. J. Hum. Genet. 2012, 20, 240-243. [CrossRef]

14. Chehade, M.; Bullock, M.; Glover, A.; Hutvagner, G.; Sidhu, S. Key MicroRNA's and their targetome in adrenocortical cancer. Cancers 2020, 12, 2198. [CrossRef]

15. Soon, P.S.H.; Tacon, L.J.; Gill, A.J.; Bambach, C.P.; Sywak, M.S.; Campbell, P.R.; Yeh, M.W.; Wong, S.G.; Clifton-Bligh, R.J.; Robinson, B.G.; et al. miR-195 and miR-483-5p identified as predictors of poor prognosis in adrenocortical cancer. Clin. Cancer Res. 2009, 15, 7684-7692. [CrossRef] [PubMed]

16. Tömböl, Z.; Szabó, P.M.; Molnár, V.; Wiener, Z.; Tölgyesi, G.; Horányi, J.; Riesz, P.; Reismann, P.; Patócs, A.; Likó, I.; et al. Integrative molecular bioinformatics study of human adrenocortical tumors: MicroRNA, tissue-specific target prediction, and pathway analysis. Endocr. Relat. Cancer 2009, 16, 895-906. [CrossRef] 
17. Patterson, E.E.; Holloway, A.K.; Weng, J.; Fojo, T.; Kebebew, E. MicroRNA profiling of adrenocortical tumors reveals miR-483 as a marker of malignancy. Cancer 2011, 117, 1630-1639. [CrossRef] [PubMed]

18. Schmitz, K.J.; Helwig, J.; Bertram, S.; Sheu, S.Y.; Suttorp, A.C.; Seggewiss, J.; Willscher, E.; Walz, M.K.; Worm, K.; Schmid, K.W. Differential expression of microRNA-675, microRNA-139-3p and microRNA-335 in benign and malignant adrenocortical tumours. J. Clin. Pathol. 2011, 64, 529-535. [CrossRef]

19. Özata, D.M.; Caramuta, S.; Velázquez-Fernández, D.; Akçakaya, P.; Xie, H.; Höög, A.; Zedenius, J.; Bäckdahl, M.; Larsson, C.; Lui, W.O. The role of microRNA deregulation in the pathogenesis of adrenocortical carcinoma. Endocr.-Relat. Cancer 2011, 18, 643-655. [CrossRef]

20. Assié, G.; Letouzé, E.; Fassnacht, M.; Jouinot, A.; Luscap, W.; Barreau, O.; Omeiri, H.; Rodriguez, S.; Perlemoine, K.; René-Corail, F.; et al. Integrated genomic characterization of adrenocortical carcinoma. Nat. Genet. 2014, 46, 607-612. [CrossRef] [PubMed]

21. Duregon, E.; Rapa, I.; Votta, A.; Giorcelli, J.; Daffara, F.; Terzolo, M.; Scagliotti, G.V.; Volante, M.; Papotti, M. MicroRNA expression patterns in adrenocortical carcinoma variants and clinical pathologic correlations. Hum. Pathol. 2014, 45, 1555-1562. [CrossRef]

22. Wang, C.; Sun, Y.; Wu, H.; Zhao, D.; Chen, J. Distinguishing adrenal cortical carcinomas and adenomas: A study of clinicopathological features and biomarkers. Histopathology 2014, 64, 567-576. [CrossRef]

23. Feinmesser, M.; Benbassat, C.; Meiri, E.; Benjamin, H.; Lebanony, D.; Lebenthal, Y.; de Vries, L.; Drozd, T.; Spector, Y. Specific MicroRNAs differentiate adrenocortical adenomas from carcinomas and correlate with weiss histopathologic system. Appl. Immunohistochem. Mol. Morphol. 2015, 23, 522-531. [CrossRef]

24. Gara, S.K.; Wang, Y.; Patel, D.; Liu, Y.; Jain, M.; Boufraqech, M.; Zhang, L.; Meltzer, P.S.; Kebebew, E. Integrated genome-wide analysis of genomic changes and gene regulation in human adrenocortical tissue samples. Nucleic Acids Res. 2015, 43, 9327-9339. [CrossRef]

25. Wu, Y.; Wang, W.; Hu, W.; Xu, W.; Xiao, G.; Nie, Q.; Ouyang, K.; Chen, S. MicroRNA-205 suppresses the growth of adrenocortical carcinoma SW-13 cells via targeting Bcl-2. Oncol. Rep. 2015, 34, 3104-3110. [CrossRef] [PubMed]

26. Zheng, S.; Cherniack, A.D.; Dewal, N.; Moffitt, R.A.; Danilova, L.; Murray, B.A.; Lerario, A.M.; Else, T.; Knijnenburg, T.A.; Ciriello, G.; et al. Comprehensive pan-genomic characterization of adrenocortical carcinoma. Cancer Cell 2016, 29, 723-736. [CrossRef] [PubMed]

27. Koperski, L.; Kotlarek, M.; Świerniak, M.; Kolanowska, M.; Kubiak-Dydo, A.; Górnicka, B.; Jażdżewski, K.; Wójcicka, A. Next-generation sequencing reveals microRNA markers of adrenocortical tumors malignancy. Oncotarget 2017, 8, 49191-49200. [CrossRef] [PubMed]

28. Koduru, S.V.; Leberfinger, A.N.; Ravnic, D.J. Small non-coding RNA abundance in adrenocortical carcinoma: A footprint of a rare cancer. J. Genom. 2017, 5, 99-118. [CrossRef] [PubMed]

29. Szabó, D.R.; Luconi, M.; Szabó, P.M.; Tóth, M.; Szücs, N.; Horányi, J.; Nagy, Z.; Mannelli, M.; Patócs, A.; Rácz, K.; et al. Analysis of circulating microRNAs in adrenocortical tumors. Lab. Investig. 2014, 94, 331-339. [CrossRef]

30. Patel, D.; Boufraqech, M.; Jain, M.; Zhang, L.; He, M.; Gesuwan, K.; Gulati, N.; Nilubol, N.; Fojo, T.; Kebebew, E. MiR-34a and miR-483-5p are candidate serum biomarkers for adrenocortical tumors. Surgery 2013, 154, 1224-1229. [CrossRef]

31. Salvianti, F.; Canu, L.; Poli, G.; Armignacco, R.; Scatena, C.; Cantini, G.; Di Franco, A.; Gelmini, S.; Ercolino, T.; Pazzagli, M.; et al. New insights in the clinical and translational relevance of miR483-5p in adrenocortical cancer. Oncotarget 2017, 8, 65525-65533. [CrossRef] [PubMed]

32. Perge, P.; Butz, H.; Pezzani, R.; Bancos, I.; Nagy, Z.; Pálóczi, K.; Nyírő, G.; Decmann, Á.; Pap, E.; Luconi, M.; et al. Evaluation and diagnostic potential of circulating extracellular vesicle-associated microRNAs in adrenocortical tumors. Sci. Rep. 2017, 7, 1-10.

33. Perge, P.; Decmann, Á.; Pezzani, R.; Bancos, I.; Fassina, A.; Luconi, M.; Canu, L.; Tóth, M.; Boscaro, M.; Patócs, A.; et al. Analysis of circulating extracellular vesicle-associated microRNAs in cortisol-producing adrenocortical tumors. Endocrine 2018, 59, 280-287. [CrossRef] [PubMed]

34. Decmann, A.; Bancos, I.; Khanna, A.; Thomas, M.A.; Turai, P.; Perge, P.; Pintér, J.Z.; Tóth, M.; Patócs, A.; Igaz, P. Comparison of plasma and urinary microRNA-483-5p for the diagnosis of adrenocortical malignancy. J. Biotechnol. 2019, 297, 49-53. [CrossRef]

35. Chabre, O.; Libe, R.; Assié, G.; Barreau, O.; Bertherat, J.; Bertagna, X.; Feige, J.-J.; Cherradi, N. Serum miR-483-5p and miR-195 are predictive of recurrence risk in adrenocortical cancer patients. Endocr. Relat. Cancer 2013, 20, 579-594. [CrossRef]

36. Decmann, A.; Perge, P.; Nyírő, G.; Darvasi, O.; Likó, I.; Borka, K.; Micsik, T.; Tóth, Z.; Bancos, I.; Pezzani, R.; et al. MicroRNA expression profiling in adrenal myelolipoma. J. Clin. Endocrinol. Metab. 2018, 103, 3522-3530. [CrossRef]

37. Faria, A.M.; Sbiera, S.; Ribeiro, T.C.; Soares, I.C.; Mariani, B.M.; Freire, D.S.; De Sousa, G.R.; Lerario, A.M.; Ronchi, C.L.; Deutschbein, T.; et al. Expression of LIN28 and its regulatory microRNAs in adult adrenocortical cancer. Clin. Endocrinol. 2014, 82, 481-488. [CrossRef]

38. Agosta, C.; Laugier, J.; Guyon, L.; Denis, J.; Bertherat, J.; Libé, R.; Boisson, B.; Sturm, N.; Feige, J.-J.; Chabre, O.; et al. MiR-483-5p and miR-139-5p promote aggressiveness by targeting N-myc downstream-regulated gene family members in adrenocortical cancer. Int. J. Cancer 2018, 143, 944-957. [CrossRef]

39. Oreglia, M.; Sbiera, S.; Fassnacht, M.; Guyon, L.; Denis, J.; Cristante, J.; Chabre, O.; Cherradi, N. Early postoperative circulating mir-483-5p is a prognosis marker for adrenocortical cancer. Cancers 2020, 12, 724. [CrossRef]

40. Glover, A.; Zhao, J.T.; Gill, A.J.; Weiss, J.; Mugridge, N.; Kim, E.; Feeney, A.L.; Ip, J.C.; Reid, G.; Clarke, S.; et al. microRNA-7 as a tumor suppressor and novel therapeutic for adrenocortical carcinoma. Oncotarget 2015, 6, 36675-36688. [CrossRef] 
41. Kwok, G.T.; Zhao, J.T.; Glover, A.R.; Gill, A.J.; Clifton-Bligh, R.; Robinson, B.G.; Ip, J.C.; Sidhu, S.B. microRNA-431 as a Chemosensitizer and Potentiator of Drug Activity in Adrenocortical Carcinoma. Oncologist 2019, 24, e241-e250. [CrossRef]

42. Nagy, Z.; Baghy, K.; Hunyadi-Gulyas, E.; Micsik, T.; Nyírő, G.; Rácz, G.; Butz, H.; Perge, P.; Kovalszky, I.; Medzihradszky, K.F.; et al. Evaluation of 9-cis retinoic acid and mitotane as antitumoral agents in an adrenocortical xenograft model. Am. J. Cancer Res. 2015, 5, 3645-3658.

43. Jung, S.; Nagy, Z.; Fassnacht, M.; Zambetti, G.; Weiss, M.; Reincke, M.; Igaz, P.; Beuschlein, F.; Hantel, C. Preclinical progress and first translational steps for a liposomal chemotherapy protocol against adrenocortical carcinoma. Endocr.-Relat. Cancer 2016, 23, 825-837. [CrossRef] [PubMed]

44. Veronese, A.; Lupini, L.; Consiglio, J.; Visone, R.; Ferracin, M.; Fornari, F.; Zanesi, N.; Alder, H.; D’Elia, G.; Gramantieri, L.; et al. Oncogenic role of miR-483-3p at the IGF2/483 locus. Cancer Res. 2010, 70, 3140-3149. [CrossRef]

45. Velázquez-Fernández, D.; Laurell, C.; Geli, J.; Höög, A.; Odeberg, J.; Kjellman, M.; Lundeberg, J.; Hamberger, B.; Nilsson, P.; Bäckdahl, M. Expression profiling of adrenocortical neoplasms suggests a molecular signature of malignancy. Surgery 2005, 138, 1087-1094. [CrossRef]

46. Caramuta, S.; Lee, L.; Özata, M.D.; Akcakaya, P.; Xie, H.; Höög, A.; Zedenius, J.; Bäckdahl, M.; Larsson, C.; Lui, W.-O. Clinical and functional impact of TARBP2 over-expression in adrenocortical carcinoma. Endocr. Relat. Cancer 2013, 20, 551-564. [CrossRef] [PubMed]

47. Jain, M.; Zhang, L.; Boufraqech, M.; Liu, Y.; Bussey, K.; Demeure, M.J.; Wu, X.; Su, L.; Pacak, K.; Stratakis, C.A.; et al. ZNF367 Inhibits Cancer Progression and Is Targeted by miR-195. PLoS ONE 2014, 9, e101423. [CrossRef]

48. Hassan, N.; Zhao, J.T.; Glover, A.; Robinson, B.G.; Sidhu, S.B. Reciprocal interplay of miR-497 and MALAT1 promotes tumourigenesis of adrenocortical cancer. Endocr. Relat. Cancer 2019, 26, 677-688. [CrossRef]

49. Doghman, M.; El Wakil, A.; Cardinaud, B.; Thomas, E.; Wang, J.; Zhao, W.; Valle, M.H.C.P.-D.; de Figueiredo, B.C.; Zambetti, G.P.; Lalli, E. Regulation of Insulin-like Growth Factor-Mammalian Target of Rapamycin Signaling by MicroRNA in Childhood Adrenocortical Tumors. Cancer Res. 2010, 70, 4666-4675. [CrossRef] [PubMed]

50. Soon, P.S.H.; Libe, R.; Benn, D.E.; Gill, A.; Shaw, J.; Sywak, M.S.; Groussin, L.; Bertagna, X.; Gicquel, C.; Bertherat, J.; et al. Loss of Heterozygosity of 17p13, With Possible Involvement of ACADVL and ALOX15B, in the Pathogenesis of Adrenocortical Tumors. Ann. Surg. 2008, 247, 157-164. [CrossRef]

51. Dang, K.; Myers, K.A. The Role of Hypoxia-Induced miR-210 in Cancer Progression. Int. J. Mol. Sci. 2015, 16, 6353-6372. [CrossRef]

52. Zhang, J.-Z.; Behrooz, A.; Ismail-Beigi, F. Regulation of glucose transport by hypoxia. Am. J. Kidney Dis. 1999, 34, 189-202. [CrossRef]

53. Emdad, L.; Janjic, A.; Alzubi, M.A.; Hu, B.; Santhekadur, P.K.; Menezes, M.E.; Shen, X.-N.; Das, S.K.; Sarkar, D.; Fisher, P.B. Suppression of miR-184 in malignant gliomas upregulates SND1 and promotes tumor aggressiveness. Neuro-Oncology 2014, 17, 419-429. [CrossRef]

54. Fang, Z.; Zhao, J.; Xie, W.; Sun, Q.; Wang, H.; Qiao, B. LncRNA UCA1 promotes proliferation and cisplatin resistance of oral squamous cell carcinoma by sunppressing miR-184 expression. Cancer Med. 2017, 6, 2897-2908. [CrossRef]

55. Lin, T.-C.; Lin, P.-L.; Cheng, Y.-W.; Wu, T.-C.; Chou, M.-C.; Chen, C.-Y.; Lee, H. MicroRNA-184 Deregulated by the MicroRNA-21 Promotes Tumor Malignancy and Poor Outcomes in Non-small Cell Lung Cancer via Targeting CDC25A and c-Myc. Ann. Surg. Oncol. 2015, 22 (Suppl. 3), 1532-1539. [CrossRef]

56. Yang, J.; Lai, C.-C.; Xian, Z.-M.; Wang, W.-Q.; Xu, B.-L. Preliminary results indicate increased expression of miR-184 in patients with renal carcinoma. Eur. Rev. Med. Pharmacol. Sci. 2019, 23, 6878-6887.

57. Xiao, F.; Zhang, W.; Chen, L.; Chen, F.; Xie, H.; Xing, C.; Yu, X.; Ding, S.; Chen, K.; Guo, H.; et al. MicroRNA-503 inhibits the G1/S transition by downregulating cyclin D3 and E2F3 in hepatocellular carcinoma. J. Transl. Med. 2013, 11, 195. [CrossRef] [PubMed]

58. Liu, H.; Song, Z.; Liao, D.; Zhang, T.; Liu, F.; Zheng, W.; Luo, K.; Yang, L. miR-503 inhibits cell proliferation and invasion in glioma by targeting L1CAM. Int. J. Clin. Exp. Med. 2015, 8, 18441-18447. [PubMed]

59. Fu, Y.; Meng, Y.; Gu, X.; Tian, S.; Hou, X.; Ji, M. miR-503 expression is downregulated in cervical cancer and suppresses tumor growth by targeting AKT2. J. Cell. Biochem. 2019, 120, 8177-8184. [CrossRef] [PubMed]

60. Rang, Z.; Yang, G.; Wang, Y.-W.; Cui, F. miR-542-3p suppresses invasion and metastasis by targeting the proto-oncogene serine/threonine protein kinase, PIM1, in melanoma. Biochem. Biophys. Res. Commun. 2016, 474, 315-320. [CrossRef]

61. Yang, C.; Wang, M.-H.; Zhou, J.-D.; Chi, Q. Upregulation of miR-542-3p inhibits the growth and invasion of human colon cancer cells through PI3K/AKT/survivin signaling. Oncol. Rep. 2017, 38, 3542-3553. [CrossRef]

62. Althoff, K.; Lindner, S.; Odersky, A.; Mestdagh, P.; Beckers, A.; Karczewski, S.; Molenaar, J.J.; Bohrer, A.; Knauer, S.; Speleman, F.; et al. miR-542-3p exerts tumor suppressive functions in neuroblastoma by downregulating Survivin. Int. J. Cancer 2014, 136, 1308-1320. [CrossRef] [PubMed]

63. Zhang, T.; Liu, W.; Meng, W.; Zhao, H.; Yang, Q.; Gu, S.-J.; Xiao, C.-C.; Jia, C.-C.; Fu, B.-S. Downregulation of miR-542-3p promotes cancer metastasis through activating TGF- $\beta$ /Smad signaling in hepatocellular carcinoma. OncoTargets Ther. 2018, 11, 1929-1939. [CrossRef]

64. He, R.-Q.; Li, X.-J.; Liang, L.; Xie, Y.; Luo, D.-Z.; Ma, J.; Peng, Z.-G.; Hu, X.-H.; Chen, G. The suppressive role of miR-542-5p in NSCLC: The evidence from clinical data and in vivo validation using a chick chorioallantoic membrane model. BMC Cancer 2017, 17, 655. [CrossRef] [PubMed] 
65. Cheng, S.; Zhang, Z.; Hu, C.; Xing, N.; Xia, Y.; Pang, B. Pristimerin suppressed breast cancer progression via miR-542-5p/DUB3 axis. OncoTargets Ther. 2020, 13, 6651-6660. [CrossRef]

66. Castilla, M.; Moreno-Bueno, G.; Romero-Pérez, L.; Van De Vijver, K.; Biscuola, M.; López-García, M.; Prat, J.; Matías-Guiu, X.; Cano, A.; Oliva, E.; et al. Micro-RNA signature of the epithelial-mesenchymal transition in endometrial carcinosarcoma. J. Pathol. 2010, 223, 72-80. [CrossRef]

67. Zhu, T.; Fan, D.; Ye, K.; Liu, B.; Cui, Z.; Liu, Z.; Tian, Y. Role of miRNA-542-5p in the tumorigenesis of osteosarcoma. FEBS Open Bio 2020, 10, 627-636. [CrossRef]

68. Rezaei, T.; Amini, M.; Hashemi, Z.S.; Mansoori, B.; Rezaei, S.; Karami, H.; Mosafer, J.; Mokhtarzadeh, A.; Baradaran, B. microRNA181 serves as a dual-role regulator in the development of human cancers. Free Radic. Biol. Med. 2019, 152, 432-454. [CrossRef] [PubMed]

69. Calin, G.A.; Sevignani, C.; Dumitru, C.D.; Hyslop, T.; Noch, E.; Yendamuri, S.; Shimizu, M.; Rattan, S.; Bullrich, F.; Negrini, M.; et al. Human microRNA genes are frequently located at fragile sites and genomic regions involved in cancers. Proc. Natl. Acad. Sci. USA 2004, 101, 2999-3004. [CrossRef] [PubMed]

70. Pigati, L.; Yaddanapudi, S.C.S.; Iyengar, R.; Kim, D.-J.; Hearn, S.A.; Danforth, D.; Hastings, M.; Duelli, D.M. Selective release of microrna species from normal and malignant mammary epithelial cells. PLoS ONE 2010, 5, e13515. [CrossRef]

71. de Sousa, G.R.V.; Ribeiro, T.C.; Faria, A.M.; Mariani, B.M.; Lerario, A.M.; Zerbini, M.C.N.; Soares, I.C.; Wakamatsu, A.; Alves, V.A.; Mendonca, B.B.; et al. Low DICER1 expression is associated with poor clinical outcome in adrenocortical carcinoma. Oncotarget 2015, 6, 22724-22733. [CrossRef] [PubMed]

72. Alshabi, A.M.; Vastrad, B.; Shaikh, I.A.; Vastrad, C. Identification of important invasion and proliferation related genes in adrenocortical carcinoma. Med. Oncol. 2019, 36, 73. [CrossRef] [PubMed]

73. Ebert, M.S.; Sharp, P.A. MicroRNA sponges: Progress and possibilities. RNA 2010, 16, 2043-2050. [CrossRef] [PubMed]

74. Dews, M.; Homayouni, A.; Yu, D.; Murphy, D.; Sevignani, C.; Wentzel, E.; Furth, E.E.; Lee, W.M.; Enders, G.H.; Mendell, J.T.; et al. Augmentation of tumor angiogenesis by a Myc-activated microRNA cluster. Nat. Genet. 2006, 38, 1060-1065. [CrossRef] [PubMed]

75. Janssen, H.L.; Reesink, H.W.; Lawitz, E.J.; Zeuzem, S.; Rodriguez-Torres, M.; Patel, K.; Van Der Meer, A.J.; Patick, A.K.; Chen, A.; Zhou, Y.; et al. Treatment of HCV infection by targeting microRNA. N. Engl. J. Med. 2013, 368, 1685-1694. [CrossRef]

76. Hantel, C.; Lewrick, F.; Reincke, M.; Süss, R.; Beuschlein, F. Liposomal doxorubicin-based treatment in a preclinical model of adrenocortical carcinoma. J. Endocrinol. 2012, 213, 155-161. [CrossRef] [PubMed] 